İşletme Akademisi Dergisi
2020,1 (3): $217-234$
DOI: $10.26677 / T R 1010.2020 .543$
Dergi web sayfasi: www.isakder.org

$\underline{\text { Araștırma Makalesi }}$

\title{
Yaratıcı Muhasebe Kavramı ve Muhasebe Meslek Mensuplarının Bilgi Düzeylerinin Ölçülmesi: Sivas İli Uygulaması ${ }^{1}$
}

\section{Esra DURAK}

Erciyes Üniversitesi İiBF İşletme Bölümü Doktora Öğrencisi esrdrk1@gmail.com, www.orcid.org/0000-0003-1242-5519

\section{Dr. Öğr. Üyesi Azize ESMERAY}

Kayseri Üniversitesi UBF Muhasebe ve Finans Yönetimi Bölümü esmeray@kayseri.edu.tr, www.orcid.org/0000-0002-3483-6258

\section{Öz}

2000'li yılların başlarında yaşanan muhasebe skandallarından sonra, finansal tablolarda aldatıcı bilgi vermeye yönelik olarak yapılan hileli finansal raporlama ve bununla ilişkili olarak yaratıcı muhasebe konusu uygulamada olduğu kadar akademik çalışmalarda da ön plana çıkmıştır. Yaşanan muhasebe skandallarının temelini yaratıcı muhasebe uygulamaları oluşturmaktadır. Bu çalışmanın amacı, muhasebe meslek mensuplarının yaratıı muhasebe kavramı ve bu kavramın uygulanabilirliği ile ilgili bilgi düzeylerini ölçmek ve yaratıcı muhasebe uygulamalarının finansal tablolar üzerinde etkisinin olup olmadığını belirlemektir. Bu doğrultuda konu ile ilgili anket çalışması uygulanarak literatüre katkı sağlanması amaçlanmıştır. Çalışma sonucunda, meslek mensuplarının yaratıcı muhasebe kavramı ve uygulamaları hakkında \%39,2'sinin hiç bilgisinin olmamasına rağmen \%30,8'inin işletmenin finansal raporlarını iyi ya da kötü yönde değiştirmeleri yönünde teklif aldığı ve bunun $\% 42,5$ oranla vergi matrahını düşük göstermek nedeniyle yapıldığı tespit edilmiştir. Bu durum meslek mensuplarının yaratıcı muhasebe uygulamaları ile ilgili kavramsal bilgilerinin yeterli düzeyde olmadığı sonucunu ortaya çıkarmıştır.

Anahtar Kelimeler: Yaratıcı Muhasebe, Muhasebe Manipülasyonu, Hile, Muhasebe Esneklikleri.

Makale Gönderme Tarihi: 07.07.2020

Makale Kabul Tarihi: 16.09 .2020

${ }^{1}$ Bu çalışma Esra Durak tarafından 2019 yılında üretilen "Bir Manipülasyon Aracı Olarak Yaratıcı Muhasebe ve Bir Uygulama" isimli yüksek lisans tezi esas alınarak hazırlanmıştır.

Önerilen Atıf:

Durak, E., Esmeray, A. (2020). Yaratıcı Muhasebe Kavramı ve Muhasebe Meslek Mensuplarının Bilgi Düzeylerinin Ölçülmesi: Sivas İli Uygulaması, İşletme Akademisi Dergisi, 1(3): 217-234.

(c) 2020 İşletme Akademisi Dergisi. 


Journal of Business Academy
2020,1(3): $217-234$
DOI:10.26677/TR1010.2020.543
Web pages: www.isakder.org

$\underline{\text { ResearchArticle }}$

\title{
Creative Accounting Concept and Measuring the Knowledge Levels of Accounting Professionals: Sivas Province Application
}

\section{Esra DURAK}

Erciyes University,Department of Business Management, Ph.D. Student esrdrk1@gmail.com, www.orcid.org/0000-0003-1242-5519

\section{Dr. Öğr. Üyesi Azize ESMERAY}

Kayseri University, Faculty of Applied Sciences, Department of Accounting and Finance Management

esmeray@kayseri.edu.tr, www.orcid.org/0000-0002-3483-6258

\begin{abstract}
After accounting scandals in the early 2000s, fraudulent financial reporting for misleading information in the financial statements and related creative accounting issues have come to the fore academically just like any other areas. In the literature, the concept of creative accounting is defined as the situation in which the financial position differs from the present state by using the deficiencies or the flexibility of various regulations related to accounting practices and by changing the presentation of the financial statements with the formal or numerical changes made on the financial statements. The objective of this study is to measure the level of knowledge of accounting professionals about the concept of creative accounting and the applicability of this concept and determine whether creative accounting practices have an impact on financial statements. In this respect, it is aimed to contribute to the literature by applying the survey on the subject. As a result of this study, $39.2 \%$ of the professional members have no knowledge of the concept and practice of creative accounting but $30.8 \%$ of them have been offered to change their financial statements in a positive or negative way and this is due to show that $42.5 \%$ of the tax base is low. This has led to the conclusion that the professional members ' conceptual knowledge of creative accounting practices is not sufficient.
\end{abstract}

Keywords: Accounting Manipulation, Creative Accounting, Fraud, Accounting Flexibilities.

Received: 07.07.2020

Accepted: 16.09 .2020

\section{Suggested Citation:}

Durak, E., Esmeray, A. (2020). Creative Accounting Concept and Measuringthe Knowledge Levels of Accounting Professionals: Sivas Province Application, Journal of Business Academy, 1(3): 217-234.

(C) 2020 Journal of Business Academy. 


\section{GİRIŞ̧}

İşletmelerde mali nitelikteki işlemler finansal bilgi kullanıcılarına finansal tablolar aracılığıyla sunulmaktadır. Bu nedenle finansal bilgi kullanıcılarının ihtiyacı; finansal tabloların dürüst, güvenilir ve gerçeği yansıtan bilgilerle hazırlanmasıdır. Özellikle 1980'li yılardan sonra yaşanan muhasebe skandallarından ötürü finansal bilgiye olan güven azalmıştır. Bu güvenin azalması sermaye piyasalarının da olumsuz etkilenmesine yol açabilmektedir. Bu yüzden finansal bilgi kullanıcıları veya yatırımcılar açısından, finansal işlemlerin sınıflandırılması, özetlenmesi, kaydedilmesi ve finansal tablo olarak oluşturulmasında Genel Kabul Görmüş Muhasebe İlkelerine (GKGMI) uyulması ile finansal bilginin güvenilirliği sağlanmış olmaktadır. İşletme ile ilgili finansal bilgilerin doğruluğu herkes için oldukça önemlidir. Buna rağmen bazı işletme yöneticileri kendi çıkarlarını düşünerek finansal bilgi kullanıcılarına manipüle adı verilen yanıltıcı bilgiler sunabilmektedir. Yapılan bu yanıltıcı eylemler, muhasebe politikalarında veya muhasebe standartlarındaki esneklik veya eksiklerden faydalanılarak yapılır ve finansal tabloların olduğundan farklı biçimde hazırlanması ve sunulmasına imkân verir.

Yaratıcı muhasebe esasen muhasebe işlemlerinde ve finansal tablolarda bir düzenleme işlemidir. İşletmenin istenildiği gibi gösterilmesi doğrultusunda birtakım düzenlemeler yapılması yaratıcı muhasebenin konusunu oluşturur. Ancak bu düzenlemeler yasal olsa da etik olmayan uygulamalardir.

Çalışmanın amacı, muhasebe manipülasyonaraçlarından biriolan yaratıcı muhasebe kavramı hakkında bilgi vererek, muhasebe meslek mensuplarının yaratıcı muhasebe uygulamaları hakkında farkındalıklarını tespit etmektir. Bu doğrultuda Sivas İlindeki meslek mensuplarına bir anket çalışması düzenlenmiştir. Çalışma üç bölümden oluşmaktadır. Öncelikle kavramsal çerçeve açıklanarak, literatür çalışması yapılmış ve son olarak anket uygulamasının sonuçları değerlendirilmiştir.

\section{KAVRAMSAL ÇERÇEVE}

Yaratıcı muhasebe uygulamaları bir manipülasyon tekniğidir. Türk Dil Kurumu manipülasyonu; yönlendirme ya da seçme, ekleme ve çıkarma aracıllğ tanımlamıştır. İşletmelerin GKGMI'nde bulunan esnekliklerden ya da eksiklerden faydalanarak raporlama yaparken faaliyet sonuçlarını mevcut durumdan farklı göstermesi yani finansal bilgiler üzerinde yaptığı değişim işlemleri ve oynamalar muhasebe manipülasyonudur (Küçüksözen ve Küçükkocaoğlu, 2004: 4).Özellikle işletmelerin, yatırımcıların fikirlerini değiştirmek ve yatırımcıların risklerle ilgili düşüncelerini olumlu yönde etkilemek için farklı muhasebe manipülasyonları uyguladıkları bilinmektedir (Varıcı ve Er, 2013: 44). Yapılan bu manipülasyonlar, muhasebe politikalarında veya muhasebe standartlarındaki esneklik veya eksiklerden faydalanılarak finansal tabloların olduğundan farklı biçimde hazırlanması ve sunulması durumu olarak açıklanabilir. Bu tür eksikleri veya esneklikleri kullanılarak yapılan uygulamalara "yaratıcı muhasebe" adı verilmektedir.

Yaratıcı muhasebe kavram olarak ilk kez Anglosakson literatüründe 1970'li yıllarda iflas etmiş olan işletmelerde yapılan incelemelerde ortaya çıkmıştır. Fakat daha sonra yazar olan Ian Griffiths 1986 yllında "Creative Accounting" adlı kitap yayımlamıştır ve bu kavram önem kazanmıştır (Aygün, 2013: 50). Yaratıcı muhasebe, "ilke ve kuralları, değerleme ölçüleri ve uygulamaya yönelik düzenlemelerin eksikliğinden faydalanıp muhasebe rakamları üzerinde farklılıklar yaparak finansal tabloların şeklini veya finansal tablolarda yer alan bilgilerin sunuluşunu değiştirerek finansal durumu olduğundan farklı göstermek amacıyla yapılan işlemlerin tümü" olarak tanımlanabilir (Saltoğlu, 2003: 108).

Yaratıcı muhasebe "Genel Kabul Görmüş Muhasebe İlkeleri" (GKGMI) dâhilinde veya bu sınırlar haricinde hileli finansal raporlama, kazanç yönetimi ve gelirin yıllar boyunca belirli bir düzeyde 
tutulmasına ilişkin uygulamaları da kapsayacak agresif tercihlerin benimsenmesinden hareketle finansal verilerle oynamaya yönelik herhangi bir adım" olarak da açıklanmıştır (Mulford ve Comiskey, 2002: 15).

Yaratıcı muhasebe uygulamalarında sıklıkla istenmeyen mevcut finansal durumun ya da faaliyet sonuçlarının saklanması yahut değiştirilmesi işlemleri yapılır. Burada mevzuattaki esnekliklerden faydalanılır ve işletmelerin/ülkelerin istedikleri sonuçlar yaratılacak şekilde kullanılır. Esas amaç işletmelerin mali tablolarını mevzuat ve standartlara uygunmuş gibi hazırlayarak mali tablo kullanıcılarının işletmeyi gerçekte olduğundan farklı algılamasını ve kararlarını işletmenin mali gerçeklerine göre değil algılarına göre yapmasını sağlamaktır. Yani kısaca yaratıcı muhasebe; işletmelerin durumunu olduğundan farklı gösterme (işletmeyi olduğundan daha iyi gösterme) durumudur (Kırbaki ve Civriz, 2013: 29).

Muhasebe politikalarındaki bazı seçmeli hususlar yaratıcı muhasebe için uygun ortamın oluşmasına sebep olmaktadır. Aslında muhasebe politikalarıyla muhasebe standartlarına uygun işleyişi sağlamak hedeflenmiş olsa da bazı konularda işletme sahipleri veya yöneticilere seçimlik hakların sağlanması durumun suiistimal edilmesine ve sonucunda yaratıcı muhasebe uygulamalarının yapılması için uygun ortamın oluşturulmasına sebebiyet vermektedir (Çıtak, 2009: 88).

Yaratıcı muhasebe uygulamalarının elbette birçok olumsuz etkisi de olmaktadır. Özellikle manipüle edilmiş finansal tablolar yatırımcıların karar alma sürecini etkileyip yanlış kararlar vermelerine yol açıp kaynakların etkin kullanılmasını önleyip ülke ekonomisine de zarar vermektedir (Demir ve Bahadır, 2007: 109). Yapılan manipülasyonun belli bir kişiye zarar vermekten öte tüm toplumu etkilediği göz önüne alınmalıdır.

\section{LITERATÜR TARAMASI}

Literatürde yaratıcı muhasebe ile ilgili yapılan çalışmalar ve bu çalışmalar sonucunda edinilen bulgular aşağıdaki gibidir.

Mert ve Başkan (2020) yaptıkları çalışmada 2011-2018 yılları arasında BİST 50 endeksinde bulunan 40 işletmenin finansal tablolarından elde ettikleri verilerle panel veri analiz yöntemi uygulanmış ve firma büyüklügünün yaratıcı muhasebeyi etkilediğini tespit etmişlerdir.

Akdoğan ve Süklüm (2019) yaptıkları çalışmada Çorum ilinde faaliyet gösteren muhasebe meslek mensuplarının algı düzeylerini ölçmek adına anket uygulaması yapmışlardır. Anket verilerinden elde edilen analizlerde katılımcıların cinsiyet ve faaliyet yeri değişkeni ile yaratıcı muhasebe algı düzeyleri arasında anlamlı bir fark bulmuşlardır.

Karahan ve Çolak (2019) yaptıkları çalışmalarında muhasebe hatası ve hileleri üzerine detaylı açılamalar yaparak yaratıcı muhasebe kavramına da değinmişlerdir ve Gaziantep ilinde üretim yapan işletmelerin muhasebe işlemlerini yürüten meslek mensupları ile bir anket çalışması yapmışlarıdır. Yaptıkları anket çalışması sonucunda hilenin uygulanmasının sebebi olarak denetimlerin yetersiz olması, giderlerin düşük gösterilmesi ve gelirlerin kaydedilmemesi yahut farklı dönemlerde kaydedilmesi durumları tespit etmişlerdir.

Suzuki ve Yamada (2016), Toshiba'da yaşanmış bir hileli muhasebe olayına dikkat çekerek, teori ve uygulama arasındaki bağlantıyı incelemişler ve muhasebe standartlarındaki boşluklar ölçüsünde, yöneticilerin finansal tabloları manipüle edebileceklerini belirterek, manipülasyonun sebebinin, muhasebe standartları olduğu sonucuna varmışladır.

Genç (2018) yapmış olduğu çalışmada bağımsız denetçilerin yaratıcı muhasebeyi nasıl algıladıklarını belirlemek için anket çalışması yapmıştır. Çalışmanın sonucunda yaratıcı muhasebe sınırlarının bağımsız denetim açısından belirlenmesi gerektiği ortaya çıkmıştır. 
Türk ve Arslan (2017) yapmış oldukları çalışmada bir şirketin Kamuyu Aydınlatma Platformu (KAP) web sitesinden bültenlerini, medyada yer alan şirket haberlerini, şirketin web sitesinde yer alan faaliyet raporlarınıyaratıcı muhasebe uygulamaları açısından araştırmışlardır. Çalışma sonucunda işletmeleri yaratıcı muhasebe uygulamalarına iten nedenlerin; yönetimin koymuş olduğu hasılat hedef baskısı, başarılı yönetici sıfatını devam ettirme isteği, yüksek kazanç beklentisi gibi gerekçeler olduğu belirlenmiştir.

Akgün (2014) yayımlanmamış yüksek lisans tezinde finansal raporlamada manipülasyon, yaratıcı muhasebe kavramı ve yaşanmış olan finansal raporlama skandallarına yer vermiştir. Çalışmada Kayseri ve Adana illerindeki meslek mensuplarının yaratıcı muhasebe uygulamaları ile ilgili bilgi düzeylerinin ölçülmesi için anket uygulanmış çalışma sonucunda Kayseri ve Adana illerindeki meslek mensuplarının yaratıcı muhasebe uygulamaları konusunda bilgili olduğu tespit edilmiştir.

Elitaş (2013) çalı̧̧masında, muhasebe manipülasyonunun muhasebe bilgi kalitesi üzerindeki etkisi ve manipülasyonun bilgi sağlamada yarattığı olumsuz sonuçlar üzerinde durmuştur. Çalışmada yapılan değerlendirmeler tamamen sezgisel yollarla elde edilen bulgular sonucunda oluşmuştur. Sonuç olarak manipülasyonun muhasebe bilgi kalitesi ölçütlerinden güvenirlilik, anlamlılık ve yararlılık ölçütlerine büyük ölçüde zarar verdiği anlaşılmıştır.

Varıcı ve Er (2013) yapmış oldukları çalışmalarında; manipülasyonun firma performansına etkisini araştırmışlardır. Çalışmada 2010 senesinde İstanbul Menkul Kıymetler Borsası 100 endeksinde bulunan 39 imalat firması seçilmiştir. Çalışmalarında manipülasyon yapan şirketler belirlenmeye çalışılırken, 11 farklı performans ölçüsü kullanılmıştır. Bu ölçüler cari oran, asit-test oranı, nakit oranı, aktif devir hızı, finansal kaldıraç oranı, finansman oranı, aktif kârlılığı, öz sermaye kârlılığı, faaliyet kâr marjı, esas faaliyet kâr marjı ve net kâr marjıdır. Çalışmanın sonucunda ise, manipülasyon yapan şirketlerin ana amacının hisse senetlerinin piyasa fiyatını etkilemek olduğu anlaşılmıştır. Manipülasyon yapan şirketlerin, manipülasyon yapmayan şirketlere göre hisse senedi piyasa fiyatları yüksek çıkmıştır.

Çıtak (2009) yaptığı çalışmada yaratıcı muhasebenin hileli finansal raporlama olup olmadığı sorusuna cevap aramıştır. Çalışmasında yaratıcı muhasebe kavramının tanımı, hile ile yaratıcı muhasebe ilişkisi ve yaratıcı muhasebe teknikleri ile ilişkisi yer almaktadır. Ayrıca hileli finansal raporlama konusuna değinilmiştir. Çalışmanın sonucunda ise, yaratıcı muhasebe uygulamalarının birer hileli finansal raporlama olduğu kanaatine varılmıştır.

Demir ve Bahadır (2007) çalışmalarında muhasebe manipülasyonlarının yöntem ve tekniklerini örneklerle açıklamaya çalışmışlardır. Bu bağlamda muhasebe manipülasyonu ve muhasebe manipülasyonlarıyla birlikte muhasebe ilke ve standartları arasındaki ilişki, muhasebe manipülasyonunun amaçları, muhasebe manipülasyonu yöntemleri ve teknikleri ayrıntılarıyla incelenmiştir.

Baralexis, (2004) çalışmasında yaratıcı muhasebe üzerine yapılan çalışmaların büyük çoğunluğunun gelişmiş sermaye piyasalarına sahip ülkelerde yapıldığını belirterek, gelişmekte olan ülkeler açısından durumu incelemek için Yunanistan'da bir çalışma yapmıştır. Çalışma sonucunda büyük şirketlerin dış finansman talebi gerekçesi ile, küçük şirketlerin vergilerini düşürmek amacıyla yaratıcı muhasebe uygulamalarına başvurduklarını tespit etmiştir.

Küçüksözen ve Küçükkocaoğlu (2004) çalışmalarında, İMKB'de işlem gören şirketlerin finansal bilgi manipülasyonlarını tahmin edebilmek için Beneish (1999) modelini revize ederek kullanmışlardır. Sonuç olarak oluşturulan modeldeki 9 açıklayıcı değişkenden yalnızca 6 tanesinin, IMKB şirketlerince yapılması muhtemel olan finansal bilgi manipülasyonu uygulamalarını ortaya çıkarmak, tahmin edebilmek için anlamlı ve yararlı olduğu belirlenmiştir. 
Saltoğlu (2003) yaptı̆̆ çalı̧̧mada dönemin en önemli skandallarından olan Enron vakası üzerinden yaratıcı muhasebe uygulamalarını incelemiştir. Çalışmada Enron tarafından özel amaçlı şirketlerin nasıl manipüle edildiği ve bunun sermaye piyasaları üzerindeki etkileri incelenmiştir. Sonuç olarak, Enron olayının yaratıcı muhasebe uygulamalarında olumsuz etkilerinin olduğu açıklanmıştır.

\section{ARAŞTIRMA YÖNTEMI}

Bu çalışmanın amacı, Sivas ilinde faaliyet gösteren meslek mensuplarının yaratıcı muhasebe ile ilgili bilgi düzeylerini ölçerek, bu konu ile ilgili davranış modellerini tespit etmektir. Bu araştırma kapsaminda, Sivas Serbest Muhasebeci Mali Müşavir Odasına tabi 300 meslek mensubu arasından kolayda örnekleme yoluyla seçilen 120 meslek mensubuna yüz yüze anket uygulaması yapılmıştır ve bu doğrultuda anket sonuçları değerlendirilmiştir. Kullanılan anket Akgün (2014) ve Genç (2018) tarafından kullanılan anketlerin derlenmesiyle oluşturulmuştur. Verilerin analizinde SPSS paket programından faydalanılmıştır. Anket verileri SPSS veri tabanına girilerek elde edilen sonuçlar ile tablolar oluşturulmuştur. Yaratıcı muhasebe uygulamaları ile demografik özellikler arasındaki ilişkiye yönelik hipotezler için parametrik test yöntemleri arasında yer alan $\mathrm{T}$ testi ve Anova testi uygulanmıştır. Uygulanmış olan anket sorularının analiz edildiği bu kısımda ilk olarak demografik özellikler, daha sonra da yaratıcı muhasebe uygulamaları ile ilgili soruların analizi yapılmıştır.

\section{ARAŞTIRMA BULGULARI}

Araştırmada yer alan bireylere ait demografik özellikler Tablo 1'deki gibidir.

Tablo 1. Demografik Özelliklere İlişkin Bulgular

\begin{tabular}{|l|c|c|}
\hline Cinsiyet & Frekans & Yüzde (\%) \\
\hline Erkek & 102 & 85,0 \\
\hline Kadın & 18 & 15,0 \\
\hline Toplam & $\mathbf{1 2 0}$ & $\mathbf{1 0 0}$ \\
\hline Eğitim & Frekans & $\mathbf{1 0 0}$ \\
\hline Ortaöğretim (Lise) & 4 & 3,3 \\
\hline Ön Lisans & 14 & 11,7 \\
\hline Lisans & 95 & 79,2 \\
\hline Yüksek Lisans & 7 & 5,8 \\
\hline Toplam & $\mathbf{1 2 0}$ & $\mathbf{1 0 0}$ \\
\hline Yaş & Frekans & Yüzde (\%) \\
\hline 25 Yaş Altı & 3 & 2,5 \\
\hline 26-35 & 22 & 18,3 \\
\hline 36-45 & 54 & 45,0 \\
\hline 46-55 & 35 & 29,2 \\
\hline 56 Yaş Üstü & 6 & 5,0 \\
\hline Toplam & $\mathbf{1 2 0}$ & $\mathbf{1 0 0}$ \\
\hline Çalışma Süresi & Frekans & Yüzde (\%) \\
\hline $0-5$ Yıl & 10 & 8,3 \\
\hline 6-10 Yıl & 11 & 9,2 \\
\hline 11-15 Yıl & 25 & 20,8 \\
\hline 15 ve Üstü & 74 & 61,7 \\
\hline Toplam & $\mathbf{1 2 0}$ & $\mathbf{1 0 0}$ \\
\hline
\end{tabular}

Sivas ilinde uygulanmış olan ankete katılan muhasebe meslek mensuplarının \%85'i erkek, \%15'i ise kadınlardan oluşmaktadır. Büyük çoğunlık erkeklerden oluşmaktadır. Bu durumun nedeni, 
muhasebe mesleğinin çalışma koşullarının erkekler için daha uygun olması olarak ifade edilebilir. Ankete katılan meslek mensuplarının \%3,3'ü ortaöğretim (lise), \%11,7'si ön lisans, $\% 79,2^{\prime}$ si lisans eğitim düzeyindedir. \%5,8'i ise yüksek lisans mezunudur. Tablo1'de görüldüğü üzere doktora derecesinde eğitimi bulunan hiç kimse yoktur. Katılımcıların çoğunluğunun lisans mezunu olduğu görülmektedir. Ankete katılan meslek mensuplarının \%8,3'ü 0 ila 5 yıl arasında, \%9,2'si 6-10 yıl, \%20,8'i 11-15 yıl, \%61,7'si ise 15 yll ve üzerinde mesleklerini icra etmektedir. Tabloda görüldüğü üzere ankete katılan meslek mensuplarının çoğunluğu mesleğini 15 yıl ve daha fazla yıldır yapmaktadır.

Tablo 2.Muhasebe Meslek Mensuplarının Mükellef Sayılarını Gösteren Frekans Dağılım Tablosu

\begin{tabular}{|l|c|c|}
\hline & Frekans & Yüzde(\%) \\
\hline 30 ve daha az & 6 & 5 \\
\hline 31-60 aras1 & 28 & 23,3 \\
\hline 61-90 aras1 & 44 & 36,7 \\
\hline 91-120 aras1 & 25 & 20,8 \\
\hline 121 ve daha üstü & 17 & 14,2 \\
\hline Toplam & 120 & 100 \\
\hline
\end{tabular}

Anket sorularını yanıtlayan meslek mensuplarının \%5'inin mükellef sayısı 30 veya daha az, \%23,3'ünün mükellef sayısı 31-60 arasında, \%36,7'sinin 61-90 arasında, \%20,8'inin 91-120 arasında ve $\% 14,2$ 'sinin 121 ve üzerindedir. Ankete katılan meslek mensuplarının bazıları almaları gereken ücretlerin alt sınırının kesin olarak belirlenmesi gerektiğini, şimdiki durumun oldukça karışıklığa yol açtığını beyan etmişlerdir.

Tablo 3.Muhasebe Meslek Mensuplarının Muhasebe Hata Bilgi Düzeyine Göre Frekans Dağılım Tablosu

\begin{tabular}{|l|c|c|}
\hline & Frekans & Yüzde(\%) \\
\hline Bilgim yok & 8 & 6,7 \\
\hline Biraz bilgim var & 41 & 34,2 \\
\hline Orta seviyede bilgim var & 52 & 43,3 \\
\hline Oldukça bilgim var & 19 & 15,8 \\
\hline Toplam & $\mathbf{1 2 0}$ & $\mathbf{1 0 0}$ \\
\hline
\end{tabular}

Tablo 3'de görüldüğü üzere meslek mensuplarının \%6,7'sinin hata hakkında biraz bilgisinin olduğu, \%34,2'sinin biraz bilgisinin olduğu, \%43,3'ünün orta seviyede bilgisinin olduğu, $\% 15,8$ 'inin ise çok bilgisinin olduğu tespit edilmiştir. Bu tablodan ankete katılan meslek mensuplarının hata hakkında yeterince bilgi sahibi oldukları kanısına varılabilir.

Tablo 4.Muhasebe Meslek Mensuplarının “Muhasebe Hatalarının Yapılmasının Nedeni Nedir?" Sorusuna Verdikleri Cevaplara Göre Frekans Dağılım Tablosu

\begin{tabular}{|l|c|c|}
\hline & Frekans & Yüzde(\%) \\
\hline Tecrübesiz olmak & 4 & 3,3 \\
\hline Dikkatsizlik, dalgin olmak & 58 & 48,3 \\
\hline İş stresi & 23 & 19,2 \\
\hline Bilgisiz olmak & 27 & 22,5 \\
\hline Teknolojik yetersizlikler & 8 & 6,7 \\
\hline Toplam & $\mathbf{1 2 0}$ & $\mathbf{1 0 0}$ \\
\hline
\end{tabular}

Tablo $4^{\prime}$ de görüldüğü üzere meslek mensupları muhasebede yapılan hataların \%3,3'ünün tecrübesiz olmaktan, \%43,8'i dikkatsiz/dalgın olmaktan, \%19,2'si iş stresinden, \%22,5' bilgisiz olmaktan ve $\% 6,7^{\prime}$ si ise teknolojik yetersizliklerden kaynaklandığını düşünmektedir. Meslek 
mensupları, hataların yapılmasının nedeninin en çok dikkatsizlik olduğunu, daha sonra da hata yapmanın bilgisizlikten kaynaklandığını düşünmektedirler.

Tablo 5.Muhasebe Meslek Mensuplarının Muhasebe Hileleri Hakkında Bilgi Düzeylerine Göre Frekans Dağılım Tablosu

\begin{tabular}{|l|c|c|}
\hline & Frekans & Yüzde(\%) \\
\hline Bilgim Yok & 11 & 9,2 \\
\hline Biraz bilgim var & 21 & 17,5 \\
\hline Orta seviyede bilgim var & 41 & 34,2 \\
\hline Oldukça bilgim var & 42 & 35 \\
\hline Çok bilgim var & 5 & 4,2 \\
\hline Toplam & $\mathbf{1 2 0}$ & $\mathbf{1 0 0}$ \\
\hline
\end{tabular}

Tablo 5'de meslek mensuplarının verdiği cevaplara göre; muhasebe hileleri hakkında $\% 4,2$ sinin çok fazla bilgiye, \%35'inin oldukça bilgiye sahip olduğu, \%34,2'sinin ise orta seviyede bilgi sahibi olduğu tespit edilmiştir. Buna karşın \%17,5'inin biraz bilgisi olduğunu, \%9,22'sinin hiç bilgisinin olmadığı belirlenmiştir. Buna karşın, anket katılımcılarının çoğunluğunun hile hakkında bilgi sahibi olduğu çıkarımında bulunulabilir.

Tablo 6.Muhasebe Meslek Mensuplarının "Muhasebe Hilelerinin Yapılmasının Nedeni Nedir?" Sorusuna Verdikleri Cevaplara Göre Frekans Dağılım Tablosu

\begin{tabular}{|l|c|c|}
\hline & Frekans & Yüzde(\%) \\
\hline Kâr artışı sağlamak & 2 & 1,7 \\
\hline Vergi matrahını düşük göstermek & 51 & 42,5 \\
\hline İşletme değerini artırmak & 7 & 5,8 \\
\hline Kötü niyetli olmak & 14 & 11,7 \\
\hline Mükellefi kaybetmemek veya mükellefi kırmamak adına & 46 & 38,3 \\
\hline Toplam & $\mathbf{1 2 0}$ & $\mathbf{1 0 0}$ \\
\hline
\end{tabular}

Tablo $6^{\prime}$ da ankete katılım sağlayan meslek mensuplarına göre muhasebede en çok yapılan hilenin \%42,5 oranla vergi matrahını düşük göstermek olduğu tespit edilmiştir. Bunu sırasıyla $\% 38,3$ oranla mükellefi kaybetmemek, \%11,7 oranla kötü niyetli olmak, \%5,8 ile işletme değerini artırmak, \%1,7 oranı ile kâr artışı sağlamak izlemektedir. Anket katılımcısı meslek mensuplarına göre hile yapmanın en önemli nedeni vergi matrahını düşük göstermektir.

Tablo 7.Muhasebe Meslek Mensuplarının “Yapılmış Muhasebe Hileleri Tespiti Ettiniz Mi?” Sorusuna Verdikleri Cevaplara Göre Frekans Dağılım Tablosu

\begin{tabular}{|l|c|c|}
\hline & Frekans & Yüzde(\%) \\
\hline Evet & 47 & 39,2 \\
\hline Hayır & 73 & 60,8 \\
\hline Toplam & 120 & 100 \\
\hline
\end{tabular}

Ankete katılım sağlayan meslek mensuplarından \%60,8'i işletme yöneticileri tarafından yapılan bir hile tespit etmemiştir. \%39,2'si ise işletme yöneticilerinin hile yaptığını tespit etmiştir. Meslek mensuplarının çoğunluk olarak işletme yöneticileri tarafından hile yapması ile karşılaşmaması olumlu bir sonuçtur. 
Tablo 8.Muhasebe Meslek Mensuplarının GKGMi' ye Aykırı Davranılmasının Talep Edilmesine İlişkin Verdikleri Cevaplara Göre Frekans Dağılım Tablosu

\begin{tabular}{|l|c|c|}
\hline & Frekans & Yüzde(\%) \\
\hline Evet & 36 & 30 \\
\hline Hayır & 84 & 70 \\
\hline Toplam & $\mathbf{1 2 0}$ & $\mathbf{1 0 0}$ \\
\hline
\end{tabular}

Tablo 8'de ankete katılım sağlayan meslek mensuplarının \%30'u kendilerine müşterileri tarafından GKGMI'ne aykırı davranmaları için talep geldiğini beyan etmiştir. Öte yandan meslek mensuplarının \%70'i ise kendilerine böyle bir talepte bulunulmadığını belirtmiştir.

Tablo 9.Muhasebe Meslek Mensuplarının “Faaliyet Sonuçlarını Değiştirmeniz Yönünde Bir

Talep ile Karşılaştınız Mı?" Sorusuna Verdikleri Cevaplara Göre Frekans Dağılım Tablosu

\begin{tabular}{|l|c|c|}
\hline & Frekans & Yüzde(\%) \\
\hline Evet & 48 & 40 \\
\hline Hayır & 72 & 60 \\
\hline Toplam & $\mathbf{1 2 0}$ & $\mathbf{1 0 0}$ \\
\hline
\end{tabular}

Tablo 9'da ankete katılım sağlayan meslek mensuplarının \%40'1 kendilerine müşterileri tarafından faaliyet sonuçlarının üzerinde olumlu veya olumsuz olarak oynanması için talep geldiğini beyan etmiştir. Meslek mensuplarının $\% 60^{\prime} 1$ ise kendilerine böyle bir talepte bulunulmadığını belirtmiştir.

Tablo 10. Muhasebe Meslek Mensuplarının “Finansal Raporları Değiştirmeniz Yönünde Bir

Talep ile Karşılaştınız mı?" Sorusuna Verdikleri Cevaplara Göre Frekans Dağılım Tablosu

\begin{tabular}{|l|c|c|}
\hline & Frekans & Yüzde(\%) \\
\hline Evet & 37 & 30,8 \\
\hline Hayır & 83 & 69,2 \\
\hline Toplam & $\mathbf{1 2 0}$ & $\mathbf{1 0 0}$ \\
\hline
\end{tabular}

Ankete katılan meslek mensuplarının \%30,8'i işletmenin finansal raporlarını iyi ya da kötü yönde değiştirmeleri için teklif aldığını, \%69,2'si ise böyle bir teklif almadığını beyan etmişlerdir.

Tablo 11.Muhasebe Meslek Mensuplarının “Mükellefleriniz Arasında Bağımsız Dıı̧ Denetim Yaptıran Var Mı? Sorusuna Verdikleri Cevaplara Göre Frekans Dağılım Tablosu

\begin{tabular}{|l|c|c|}
\hline & Frekans & Yüzde(\%) \\
\hline Evet & 0 & 0 \\
\hline Hayir & 120 & 100 \\
\hline Toplam & $\mathbf{1 2 0}$ & $\mathbf{1 0 0}$ \\
\hline
\end{tabular}

Sivas ilinde ankete katılan meslek mensuplarından hiçbirinin dış denetim yaptıran mükellefi bulunmadığı tespit edilmiştir. Buradan Sivas'taki işletmelerin belli bir ölçek altında olduğu sonucu çıkarılmaktadır.

Tablo 12.Muhasebe Meslek Mensuplarının "Yaratıcı Muhasebe Uygulamaları Tanımını Duydunuz Mu? Sorusuna Verdikleri Cevaplara Göre Frekans Dağılım Tablosu

\begin{tabular}{|l|c|c|}
\hline & Frekans & Yüzde(\%) \\
\hline Evet & 55 & 45,8 \\
\hline Hayır & 65 & 54,2 \\
\hline Toplam & $\mathbf{1 2 0}$ & $\mathbf{1 0 0}$ \\
\hline
\end{tabular}

Anket katılımcısı meslek mensuplarının $\% 45,8^{\prime} i$ daha önce yaratıcı muhasebe uygulamaları tanımını duyduğunu söylemiştir. Meslek mensuplarının geri kalan $\% 54,2^{\prime}$ si daha önce hiç bu tanımı duymadıklarını beyan etmişlerdir. 
Tablo 13. Muhasebe Meslek Mensuplarının Yaratıcı Muhasebe Uygulamaları Hakkında Bilgi Düzeylerine Göre Frekans Dağılım Tablosu

\begin{tabular}{|l|c|c|}
\hline & Frekans & Yüzde(\%) \\
\hline Bilgim yok & 47 & 39,2 \\
\hline Biraz bilgim var & 33 & 27,5 \\
\hline Orta seviyede bilgim var & 30 & 25 \\
\hline Oldukça bilgim var & 10 & 8,3 \\
\hline Toplam & $\mathbf{1 2 0}$ & $\mathbf{1 0 0}$ \\
\hline
\end{tabular}

Tablo 13'de görüleceği üzere muhasebe meslek mensuplarının $\% 39,2$ 'sinin yaratıcı muhasebe uygulamaları ile ilgili hiç bilgilerinin olmadığı, \%27,5'inin az bilgisi olduğu, \%25'inin ise orta seviyede bilgi sahibi olduğu ve son olarak \%8,3'ünün çok bilgisinin olduğu tespit edilmiştir. Bu durum gösteriyor ki Sivas ilindeki meslek mensuplarının yaratıcı muhasebe ile ilgili bilgileri yeterli düzeyde değildir.

Tablo 14.Muhasebe Meslek Mensuplarının "Yaratıcı Muhasebe Uygulamaları ve Hile Arasındaki İlişki Nedir? Sorusuna Verdikleri Cevaplara Göre Frekans Dağılım Tablosu

\begin{tabular}{|l|c|c|}
\hline & Frekans & Yüzde(\%) \\
\hline Aynı anlamdadırlar. & 32 & 26,7 \\
\hline Anlamları farklıdır. & 41 & 34,2 \\
\hline İki kavram birbirinden net biçimde ayrılamaz. & 24 & 20 \\
\hline Diğer & 23 & 19,2 \\
\hline Toplam & $\mathbf{1 2 0}$ & $\mathbf{1 0 0}$ \\
\hline
\end{tabular}

Anket sorularını yanıtlayan meslek mensuplarının \%34,2'si yaratıcı muhasebe ve hilenin anlamlarının farklı olduğunu düşündüklerini belirtmişlerdir. Öte yandan \%26,7'si anlamlarının aynı olduğunu beyan etmişlerdir. Katılımcıların \%20'si ise kavramların net şekilde ayrılamayacağını beyan etmiştir. \%19,2'lik kısım ise, kavramların diğer bir şekilde ifade edileceğini düşündüklerini beyan etmişlerdir.

Tablo 15. Muhasebe Meslek Mensuplarının Yaratıcı Muhasebe Uygulamalarına Başvurmanın İşletmeye Etkisine İlişkin Verdikleri Cevaplara Göre Frekans Dağılım Tablosu

\begin{tabular}{|l|c|c|}
\hline & Frekans & Yüzde(\%) \\
\hline İşletmenin durumunu daha iyi göstermek & 47 & 39,2 \\
\hline İşletmenin durumunu daha kötü göstermek & 1 & 0,8 \\
\hline Daha az vergi ödemek & 29 & 24,2 \\
\hline Daha az kâr payı dağıtmak & 1 & 0,8 \\
\hline İsletme hisselerinin fiyatlarını arttırmak & 1 & 0,8 \\
\hline İşletmenin kredibilitesini artırmak & 26 & 21,7 \\
\hline Diğer & 15 & 12,5 \\
\hline Toplam & $\mathbf{1 2 0}$ & $\mathbf{1 0 0}$ \\
\hline
\end{tabular}

Meslek mensuplarının \%39,2'si yaratıcı muhasebe uygulamalarına başvurma nedeni olarak işletmenin durumunu iyi göstermek olduğunu ilk sırada gördüklerini beyan etmişlerdir. Bunu $\% 24,2^{\prime}$ lik oran ile daha az vergi ödemek, \%21,72 ile kredibiliteyi artırmak, \%12,5'lik kısım ise diğer etmenlerin amaç olarak belirleneceği fikrine sahip olduğunu bildirmiştir. Ankete katılan meslek mensuplarının yaklaşık \%40'lık kesiminin düşüncesine göre yaratıcı muhasebe 
uygulamaları yapmadaki temel amacın işletmenin durumunu iyi göstermek olduğu tespit edilmektedir.

Tablo 16.Muhasebe Meslek Mensuplarının “Yöneticileri Yaratıcı Muhasebe Uygulamalarına İten Nedenler Nelerdir?" Sorusuna Verdikleri Cevaplara Göre Frekans Dağılım Tablosu

\begin{tabular}{|l|c|c|}
\hline & Frekans & Yüzde(\%) \\
\hline Kurumsal nedenler & 47 & 39,2 \\
\hline Kişisel nedenler & 49 & 40,8 \\
\hline Yasal nedenler & 24 & 20 \\
\hline Toplam & 120 & 100 \\
\hline
\end{tabular}

Ankete katılım sağlayan meslek mensuplarının \%40,8'i yaratıcı muhasebenin kişisel nedenlerle yapıldığını, \%39,2'si ise, kurumsal nedenlerle, \%20'si de yasal nedenlerle yapıldığını düşündüğünü beyan etmiştir. Anket katılımcıları yaratıcı muhasebenin daha çok kişisel nedenlerle yapıldığını düşündüklerini beyan etmişlerdir.

Tablo 17.Muhasebe Meslek Mensuplarının Yaratıcı Muhasebe Uygulamaları Yapmaları Yönünde Talep Alıp Almadıkları ile İlgili Soruya Verdikleri Cevaplara Göre Frekans Dağılım

Tablosu

\begin{tabular}{|l|c|c|}
\hline & Frekans & Yüzde (\%) \\
\hline Evet & 26 & 21,7 \\
\hline Hayır & 94 & 78,3 \\
\hline Toplam & $\mathbf{1 2 0}$ & $\mathbf{1 0 0}$ \\
\hline
\end{tabular}

Ankete katılan meslek mensuplarının \%78,3'ü mükellefleri tarafından böyle bir teklif almadıklarını belirtirken, \%21,7'si ise mükellefleri tarafından yaratıcı muhasebe uygulamaları yapmaları için teklif aldıklarını beyan etmiştir. Sivas ilinde meslek mensuplarının yaratıcı muhasebe uygulamaları yapmaları için talep yoğun değildir.

Tablo 18.Muhasebe Meslek Mensuplarının "Yaratıcı Muhasebe Uygulamaları Yapmalarının İşletmeye Etkisi Nedir? Sorusuna Verdikleri Cevaplara Göre Frekans Dağılım Tablosu

\begin{tabular}{|l|c|c|}
\hline & Frekans & Yüzde(\%) \\
\hline İşletmenin imajını güçlendirmek & 24 & 20 \\
\hline Yatırımları çekmek & 2 & 1,7 \\
\hline Kredi alabilmek & 80 & 66,7 \\
\hline İşletmenin borsa değerini arttırmak & 1 & 0,8 \\
\hline Diğer & 13 & 10,8 \\
\hline Toplam & $\mathbf{1 2 0}$ & $\mathbf{1 0 0}$ \\
\hline
\end{tabular}

Anket katılımcısı meslek mensuplarının \%20'si finansal tabloların iyi gösterilmesinin işletmeye katkısı olarak işletmenin imajını güçlendirmek, \%1,7'si yatırımları çekmek, \%66,7'si ise işletmenin kredi alabilmesini sağlamak, \%0,8'i borsa değerini artırmak ve \%10,8'i diğer hedeflerin olabileceğini beyan etmiştir. Meslek mensuplarından hiç kimse yüksek prim veya ikramiye dağıtmak seçeneğini işaretlememiştir. Büyük bir çoğunluk kredi alabilmek için bu uygulamanın yapılacağ görüşündedir. 
Tablo 19. Muhasebe Meslek Mensuplarının Mali Tablolara İlişkin Dip Notları İnceleme Konusuna Verdikleri Cevaplara Göre Frekans Dağılım Tablosu

\begin{tabular}{|l|c|c|}
\hline & Frekans & Yüzde(\%) \\
\hline Hiç dikkate almam & 5 & 4,2 \\
\hline Nadiren dikkate alırım & 12 & 10 \\
\hline Bazen dikkate alırım & 21 & 17,5 \\
\hline Sıklıkla dikkate alırım & 30 & 25 \\
\hline Her zaman dikkate alırım & 52 & 43,3 \\
\hline Toplam & $\mathbf{1 2 0}$ & $\mathbf{1 0 0}$ \\
\hline
\end{tabular}

Meslek mensuplarının \%4,2'si işletmenin finansal tablolarında bulunan dipnotları hiç dikkate almadığını, \%10'u nadiren dikkate aldığını, \%17,5'inin bazen dikkate aldığını, \%25'inin genellikle dikkate aldığı ve \%43,3'ünün her zaman dikkate aldığı tespit edilmiştir. Bu durumda meslek mensuplarının pek çok ayrıntıyı içinde bulunduran dipnotları yeterince dikkate aldıkları tespitinde bulunulabilir.

Tablo 20.Muhasebe Meslek Mensuplarının “Bir İşletmenin Hisse Senetlerini Almayı Düşündügünüzde Denetlenmiş Finansal Raporları Hangi Sıklıkla İncelersiniz?" Sorusuna Verdikleri Cevaplara Göre Frekans Dağılım Tablosu

\begin{tabular}{|l|c|c|}
\hline & Frekans & Yüzde(\%) \\
\hline Hiç incelemem & 3 & 2,5 \\
\hline Nadiren incelerim & 10 & 8,3 \\
\hline Bazen incelerim & 18 & 15 \\
\hline Siklıkla incelerim & 36 & 30 \\
\hline Her zaman incelerim & 53 & 44,2 \\
\hline Toplam & $\mathbf{1 2 0}$ & $\mathbf{1 0 0}$ \\
\hline
\end{tabular}

Meslek mensuplarının \%2,5'i bir işletmenin hisse senetlerini satın alacakları zaman denetlenmiş finansal raporları hiç incelemediğini, \%8,3'ü nadiren incelediğini, \%15'i bazen incelediğini, $\% 30$ 'u genellikle incelediği ve $\% 44,2$ 'si her zaman incelediğini beyan etmişlerdir. Genel olarak denetim raporlarının meslek mensuplarınca incelendiği tespit edilmiştir.

Tablo 21.Muhasebe Meslek Mensuplarının “Ülkemizdeki Yasal Düzenlemeler Hata ve Hileyi Önlemek Adına Yeterli Midir? Sorusuna Verdikleri Cevaplara Göre Frekans Dağılım Tablosu

\begin{tabular}{|l|c|c|}
\hline & Frekans & Yüzde(\%) \\
\hline Evet & 38 & 31,7 \\
\hline Hayır & 82 & 68,3 \\
\hline Toplam & $\mathbf{1 2 0}$ & $\mathbf{1 0 0}$ \\
\hline
\end{tabular}

Ankete katılım sağlayan meslek mensuplarının \%31,7'sinin Türkiye'deki yasal düzenlemelerin hile ve hatayı önlemek için yeterli bulduğu tespit edilirken, buna karşın \%68,3'ünün yasal düzenlemeleri yeterli bulmadığı tespit edilmiştir. Bu beyanlardan yola çıkarak ülkemizdeki yasal düzenlemelerin hata ve hileyi önlemek için yetersiz kaldığı düşüncesinin yaygın olduğu görüşünde bulunulabilir. Bu durumda yasal düzenlemelerin tekrar gözden geçirilmesi ve hata ve hileyi önlemek adına caydırıcı cezalar getirilmesi önerisinde bulunulabilir ve bu konu hakkında farklı araştırmalar yapılabilir. 
Tablo 22.Muhasebe Meslek Mensuplarının "Hata ve Hile İle Karşılaştığınızda İ̉barda Bulunuyor Musunuz? “Sorusuna Verdikleri Cevaplara Göre Frekans Dağılım Tablosu

\begin{tabular}{|l|c|c|}
\hline & Frekans & Yüzde(\%) \\
\hline Evet & 99 & 82,5 \\
\hline Hayır & 21 & 17,5 \\
\hline Toplam & $\mathbf{1 2 0}$ & $\mathbf{1 0 0}$ \\
\hline
\end{tabular}

Ankete katılan meslek mensuplarının \%82,5'i eğer hata ve hile ile karşılaşıyorsa gerekli uyarı ve ihbarları yaptığını beyan etmiştir. Bu oldukça yüksek bir orandır ve oldukça olumlu bir durumdur. Bilinçli muhasebe meslek mensuplarının olması ülkemiz adına umut vaat edicidir. $\% 17,5^{\prime} i$ ise hata ve hile ile karşılaştı̆̆ 1 durumda ihbar ve uyarı yapmadığını belirtmiştir.

Tablo 23.Muhasebe Meslek Mensuplarının “Mükellef Menfaati İçin Yanıltıcı Bilgi Veremez." İfadesine Verdikleri Cevaplara Göre Frekans Dağılım Tablosu

\begin{tabular}{|l|c|c|}
\hline & Frekans & Yüzde(\%) \\
\hline Kesinlikle Katılmıorum & 7 & 5,8 \\
\hline Katılmıyorum & 5 & 4,2 \\
\hline Ne katılıyorum ne katılmiyorum & 6 & 5 \\
\hline Katıliyorum & 46 & 38,3 \\
\hline Kesinlikle katılıyorum & 56 & 46,7 \\
\hline Toplam & $\mathbf{1 2 0}$ & $\mathbf{1 0 0}$ \\
\hline
\end{tabular}

Ankete katılan meslek mensuplarının \%46,7'si mükelleflerini korumak için topluma ve devlete yanıltıcı bilgi veremeyeceği görüşüne kesinlikle katıldığını beyan etmiştir. \%38,3'ü bu görüşe katıldığını, \%5'i kararsız olduğunu, \%4,2'si katılmadığını ve \%5,8'inin kesinlikle katılmadığını beyan etmişlerdir.

Tablo 24.Muhasebe Meslek Mensuplarının “Toplumun Menfaatlerini Mükelleflerinin Menfaati Üstünde Tutmalıdır." İfadesine Verdikleri Cevaplara Göre Frekans Dağılım Tablosu

\begin{tabular}{|l|c|c|}
\hline & Frekans & Yüzde(\%) \\
\hline Kesinlikle Katılmiyorum & 4 & 3,3 \\
\hline Katılmiyorum & 15 & 12,5 \\
\hline Ne katıllyorum ne katılmiyorum & 29 & 24,2 \\
\hline Katıliyorum & 30 & 25 \\
\hline Kesinlikle katıliyorum & 42 & 35 \\
\hline Toplam & $\mathbf{1 2 0}$ & $\mathbf{1 0 0}$ \\
\hline
\end{tabular}

Tablo 24'degörüldügü üzere meslek mensuplarının, toplumun ve devletin menfaatlerini mükelleflerinin menfaatlerinden üstün tutmalıdır sorusuna \%35'i kesinlikle katıldığını, \%25'i katıldığı, \%24,2'si ne katıldığı ne katılmadığını, \%12,5'i katılmadığını ve \%3,3'ü kesinlikle katılmadığını ifade etmiştir. Bu durumdan anlaşıldığı üzere söz konusu yargıya katılma yüksek olsa da çekimser kalanlar da azımsanmayacak kadar fazladır diyebiliriz.

Tablo 25.Muhasebe Meslek Mensuplarının “Mükellef ile Ücret Haricinde Borç İlişkisi Olmamalıdır." İfadesine Verdikleri Cevaplara Göre Frekans Dağılım Tablosu

\begin{tabular}{|l|c|c|}
\hline & Frekans & Yüzde(\%) \\
\hline Kesinlikle Katılmiyorum & 8 & 6,7 \\
\hline Katılmiyorum & 11 & 9,2 \\
\hline Ne katıliyorum ne katılmiyorum & 21 & 17,5 \\
\hline
\end{tabular}




\begin{tabular}{|l|c|c|}
\hline Katıliyorum & 36 & 30 \\
\hline Kesinlikle katıliyorum & 44 & 36,7 \\
\hline Toplam & $\mathbf{1 2 0}$ & $\mathbf{1 0 0}$ \\
\hline
\end{tabular}

Meslek mensuplarının \%36,7'si müşterisi ile alacağı ücret dışında borç-alacak ilişkisi bulunmaması gerektiği yargısına kesinlikle katıldığını belirtmiştir. \%30'u katıldığını, \%17,5'i ne katıldığını ne katılmadığını, \%9,2'si katılmadığını, \%6,7'si kesinlikle katılmadığını belirtmiştir.

Tablo 26.Muhasebe Meslek Mensuplarının “Meslek Mensubu Karar Vermesini Etkileyecek İltimaslardan Uzak Durmalıdır." İfadesine Verdikleri Cevaplara Göre Frekans Dağılım Tablosu

\begin{tabular}{|l|c|c|}
\hline & Frekans & Yüzde(\%) \\
\hline Kesinlikle Katılmiyorum & 6 & 5 \\
\hline Ne katıllyorum ne katılmiyorum & 18 & 15 \\
\hline Katıliyorum & 44 & 36,7 \\
\hline Kesinlikle katıllyorum & 52 & 43,3 \\
\hline Toplam & $\mathbf{1 2 0}$ & $\mathbf{1 0 0}$ \\
\hline
\end{tabular}

Meslek mensuplarının kararlarını etkileyecek iltimaslardan uzak durmaları gereklidir sorusuna katılımcıların \%43,3'ü kesinlikle katıldığını, \%36,7'si katıldığını, \%15'i çekimser kaldığını ve \%5'i kesinlikle katılmadığını belirtmiştir.

Tablo 27.Muhasebe Meslek Mensuplarının “Mükelleflerinden Pahalı Hediyeler Almamaları Gereklidir." İfadesine Verdikleri Cevaplara Göre Frekans Dağılım Tablosu

\begin{tabular}{|l|c|c|}
\hline & Frekans & Yüzde(\%) \\
\hline Kesinlikle Katılmiyorum & 5 & 4,2 \\
\hline Katılmiyorum & 5 & 4,2 \\
\hline Ne katıliyorum ne katılmiyorum & 18 & 15 \\
\hline Katıliyorum & 49 & 40,8 \\
\hline Kesinlikle katıliyorum & 43 & 35,8 \\
\hline Toplam & $\mathbf{1 2 0}$ & $\mathbf{1 0 0}$ \\
\hline
\end{tabular}

Meslek mensupları mükelleflerinden pahalı hediyeler kabul etmemelidir sorusuna katılımcıların \%35,8'i kesinlikle katıldığını, \%40,8'i katıldığını, \%15'i çekimser kaldığını, \%4,2'si katılmadığını ve $\% 4,2$ 'si kesinlikle katılmadığını beyan etmiştir.

Tablo 28.Muhasebe Meslek Mensuplarının "Müşterileri ile Ortaklık Kurmamaları Gereklidir." İfadesine Verdikleri Cevaplara Göre Frekans Dağılım Tablosu

\begin{tabular}{|l|c|c|}
\hline & Frekans & Yüzde(\%) \\
\hline Kesinlikle Katılmiyorum & 10 & 8,3 \\
\hline Katılmiyorum & 22 & 18,3 \\
\hline Ne katıliyorum ne katılmiyorum & 20 & 16,7 \\
\hline Katıliyorum & 32 & 26,7 \\
\hline Kesinlikle katıliyorum & 36 & 30 \\
\hline Toplam & $\mathbf{1 2 0}$ & $\mathbf{1 0 0}$ \\
\hline
\end{tabular}

Ankete katılan meslek mensuplarının \%30'u mükellefleri ile ortaklık kurmamaları gerektiği yargısına kesinlikle katıldıklarını beyan etmiştir. \%26,7'si bu görüşe katıldığını, \%16,7' si kararsız olduğunu, \%18,3'ü katılmadığını ve \%8,3’ü kesinlikle katılmadığını belirtmiştir. 
Tablo 29. Meslek Mensuplarının “Denetim Faaliyetini Yapan Meslek Mensuplarının, Denetim ile İlgili Ücretin Denetimden Önce Kararlaştırılması Gereklidir." İfadesine Meslek Mensuplarının Verdikleri Cevaplara Göre Frekans Dağılım Tablosu

\begin{tabular}{|l|c|c|}
\hline & Frekans & Yüzde(\%) \\
\hline Kesinlikle Katılmiyorum & 3 & 2,5 \\
\hline Katılmiyorum & 8 & 6,7 \\
\hline Ne katıllyorum ne katılmiyorum & 25 & 20,8 \\
\hline Katıliyorum & 48 & 40 \\
\hline Kesinlikle katıllyorum & 36 & 30 \\
\hline Toplam & $\mathbf{1 2 0}$ & $\mathbf{1 0 0}$ \\
\hline
\end{tabular}

Ankete katılan meslek mensuplarının \%30'u denetimden önce ücret kararlaştırılmalıdır yargısına kesinlikle katıldığını beyan etmiştir. \%40'ı bu görüşe katıldığını, \%20,8'i ne katıldığını ne katılmadığını, \%6,7'si katılmadığını ve \%2,5'i kesinlikle katılmadığını ifade etmiştir.

Örneklem boyutu 120 kişi olan muhasebe meslek mensuplarının muhasebe etik ve tutumları ile ilgili sorulara verdikleri cevapların ortalama ve St. Sapma değerleri aşağıdaki Tablo 30'daverilmiştir.

Tablo 30.Muhasebe Meslek Mensupları ile İlgili Yargılara Katılma Dereceleri ile İlgili Sorulara Verilen Cevapların Ortalaması ve St. Sapmaları

\begin{tabular}{|l|l|l|l|}
\hline & n & $\begin{array}{l}\text { Ortalama } \\
\text { [1-5 Arasi })\end{array}$ & $\begin{array}{l}\text { Std. } \\
\text { Sapma }\end{array}$ \\
\hline $\begin{array}{l}\text { Meslek mensubu, müşteri menfaatlerini korumak amacıyla, } \\
\text { muhasebe bilgilerinden ve finansal raporlardan faydalananlara } \\
\text { yanıltıcı bilgiler veremez. }\end{array}$ & 120 & 4,1583 & 1,09234 \\
\hline $\begin{array}{l}\text { Meslek mensubu, her koşulda devletin ve toplumun menfaatlerini, } \\
\text { müşterisinin ve kendi menfaatinin önünde tutmalıdır. }\end{array}$ & 120 & 3,7583 & 1,15951 \\
\hline $\begin{array}{l}\text { Meslek mensubu, müşterileri ile ücret dışında borç-alacak ilişkisi } \\
\text { kurmamalıdır. }\end{array}$ & 120 & 3,8083 & 1,21818 \\
\hline $\begin{array}{l}\text { Meslek mensubu kararlarını ve faaliyetlerini etkileyecek her türlü } \\
\text { iltimastan uzak durmalıdır. }\end{array}$ & 120 & 4,1333 & 1,01197 \\
\hline $\begin{array}{l}\text { Meslek mensubu, müşterilerinden yüksek değerli veya toplumca } \\
\text { uygun görülmeyecek hediyeler almamalıdır. }\end{array}$ & 120 & 4,0000 & 1,02899 \\
\hline Meslek mensubu, müşteri işletmeler ile ortaklık kurmamalıdır. & 120 & 3,5167 & 1,31560 \\
\hline $\begin{array}{l}\text { Denetim faaliyeti yürüten meslek mensupları, denetim faaliyeti ile } \\
\text { ilgili ücret konusunda denetimden önce müşteri ile anlaşmaya } \\
\text { varmalıdır. }\end{array}$ & 120 & 3,8833 &, 99734 \\
\hline Toplam & 120 & & \\
\hline
\end{tabular}

Tablo 30'da görüldügü üzere meslek mensuplarının ilgili sorulara verdikleri cevaplarda ortalaması en yüksek olan 4,1583 ortalama ile ilk sorudur. Buradan ilk sorunun en olumlu ve en çok algılanan soru olduğu ve bunun derecesinin kesinlikle katıllyorum derecesine denk geldiği söylenebilir. Bu soruların içerisinde, 3,5167 ortalama ile meslek mensuplarının müşteri ile ortak olmaması görüşü ise ne katılıyorum ne katılmıyorum derecesindedir. Buradan Sivas ilinde faaliyet gösteren meslek mensuplarının profesyonellik ve etik açısından eksikleri olduğu 
kanısına varılmaktadır. Genel ortalama ise, 3,8940'dır. Buradan cevapların genel ortalamasının katıllyorum derecesinde olduğu söylenebilir.

\section{Normallik Testi}

Verilerin normal dağılıp dağılmadığının tespit edilmesinde Kolmogorov-Smirnov ve ShapiroWilk değerleri tespit edilmiştir. Shapiro-Wilkdeğerlerinin $0,05^{\prime}$ ten büyük olması beklenmektedir. Bu koşulun yerine geldiği durumlarda verilerin normal dağılıma sahip olduğu varsayılır.

Tablo 31.Normallik Testi Tablosu

\begin{tabular}{|c|c|c|c|c|c|c|}
\hline & \multicolumn{3}{|c|}{ Kolmogorov-Smirnov $^{\text {a }}$} & \multicolumn{3}{c|}{ Shapiro-Wilk $^{*}$} \\
\cline { 2 - 7 } & İstatistik & $\mathrm{df}$ & $\mathrm{p}$ & İstatistik & $\mathrm{df}$ & $\mathrm{p}$ \\
\hline$\omega$ &, 095 & 120 &, 010 &, 979 & 120 &, 055 \\
\hline
\end{tabular}

$\omega$ : Yaratıcı muhasebe uygulamaları ile ilgili sorulara verilen cevapların ortalama değeri

Bu sonuçlara göre Burada "Shapiro-Wilk" testinin "p" değeri 0.05'den büyük olduğu için soruların ortalaması için H0 hipotezleri kabul edilir. Yani tüm gruplar için dağılımın normal dağılımdan anlamlı bir farklılık sergilemediği yorumu yapılabilir.

Tablo 32. Yaratıcı Muhasebe Uygulamaları ile İlgili Bilgi Düzeyi ve Cinsiyet İlişkine Ait T Testi Sonuçları

\begin{tabular}{|l|l|l|l|l|l|l|}
\hline Grup & $\mathbf{n}$ & Ortalama & Standart Sapma & $\mathbf{t}$ & $\mathbf{d f}$ & $\mathbf{p}$ \\
\hline Erkek & 102 & 2,8627 & 1,342 & $-1,201$ & 118 &, 232 \\
\hline Kadın & 18 & 3,2778 & 1,406 & & & \\
\hline
\end{tabular}

H0: Katılımcıların yaratıcı muhasebe uygulamaları hakkındaki bilgi düzey algıları ile cinsiyetleri arasında anlamlı bir farklılık göstermemektedir.

H1: Katılımcıların yaratıı muhasebe uygulamaları hakkındaki bilgi düzey algıları ile cinsiyetleri arasında anlamlı bir farklılık göstermektedir.

Hipotezlerimiz yukarıdaki gibi kurulduğunda tablo 32' dekip değerine bakıldığında 0,232>0,05 olduğundan H0 reddedilemez. Böylece, yaratıcı muhasebe uygulamaları hakkında ne kadar bilgili olduğunuzu düşünüyorsunuz? sorusunu algılama düzeyleri ile cinsiyet arasında anlamlı bir farklılık bulunmamaktadır.

Tablo 33. Yaratııı Muhasebe Uygulamaları ile İlgili Bilgi Düzeyi ve Eğitim Düzeylerine İlişkin Anova Tablosu

\begin{tabular}{|l|l|l|l|l|l|}
\hline & Kareler Toplamı & df & $\begin{array}{l}\text { Ortalama } \\
\text { kare }\end{array}$ & F & p \\
\hline Gruplar arası & 8,277 & 3 & 2,759 & 1,524 &, 212 \\
\hline Gruplar içi & 210,048 & 116 & 1,811 & & \\
\hline Toplam & 218,325 & 119 & & & \\
\hline
\end{tabular}

Tabloda 33'deki p değerine baktığımızda, 0,212>0,05 olduğu görülmektedir. Bu durumda p>0,05 olduğundan yaratıı muhasebe uygulamaları ile eğitim düzeyleri arasında anlamlı bir farklılık yoktur diyebiliriz. 


\section{SONUÇ}

Yaratıcı muhasebe kavramının uygulanması telaffuz edilmesinden çok önce zamanlara dayanır. Muhasebe kayıtları ve finansal tablolara müdahale edilip edilmediği muhasebe denetiminin her zaman ilgi alanına girmiştir. Yaratıcı muhasebe uygulamaları, aslında muhasebe ilke ve standartlarındaki eksiklik ya da esnekliklerden faydalanıp, işletmenin durumunu olduğundan farklı gösterme işlemleridir. Buna rağmen; yaratıcı muhasebenin, finansal bilgileri gerçek ve güvenilir sunmasına engel olan ve hileye yatkın yapısı nedeniyle, tamamen olumsuz değerlendirilmemesi gerekir. Yaratıcı muhasebe uygulamalarının olmaması aslında bir çözüm değildir. Yaratıcı muhasebenin hiç var olmaması muhasebe özgürlügünün bütün olarak kısıtlanması anlamına gelir ki; bu mümkün değildir. Bu yüzden bazı yaratıcı muhasebe uygulamaları doğal olarak vardır. Çünkü yaratıcı muhasebe uygulamalarının büyük bölümü tahakkuk muhasebesinin doğal bir sonucudur.

Çalışma; Sivas ilinde faaliyet gösteren muhasebe meslek mensuplarının yaratıcı muhasebe uygulamaları hakkında bilgi düzeylerini belirlemek ve müşterilerinin yaratıcı muhasebe uygulamalarını yapmalarını isteyip istemediklerinin tespit etmek için yapılmıştır.

Yaratıcı muhasebe uygulamaları hakkında bilgilerinin ölçülmesi için Sivas il merkezinde rastgele seçilen 120 meslek mensubuna uygulanan anket çalışması sonucunda; meslek mensuplarının $\% 39,2$ 'sinin yaratıcı muhasebe uygulamaları hakkında hiç bilgisinin olmadığı belirlenmiştir. $\% 27,5^{\prime}$ inin az bilgisi olduğu, \%25'inin orta seviyede bilgisi olduğu ve \%8,3'ünün ise oldukça bilgisi olduğu belirlenmiştir. Bu durum göstermektedir ki; meslek mensupları yaratıcı muhasebe uygulamaları ile ilgili yeterli seviyede bilgiye sahip değildir. Ankete katılım sağlayan meslek mensuplarının \%39,2'si yaratıcı muhasebeye başvurma nedeninin işletmenin durumunu iyi göstermek olduğunu belirtmişlerdir. Ayrıca yaratıcı muhasebe uygulamalarının kişisel nedenlerle yapıldığını \%40,8 oranla belirtmişlerdir. Ankete katılan meslek mensuplarının $\% 78,3$ 'ü kendilerine yaratıcı muhasebe uygulamaları yapmaları yönünde talepte bulunulmadığını belirtmişlerdir. Ülkemizdeki yasal düzenlemelerin hata ve hileyi önlemek adına yeterli görüp görmedikleri sorusuna ise; meslek mensupları \%68,3 oranında hayır cevabını vermişlerdir. $\mathrm{Bu}$ durum ayrıca ele alınmalı ve üzerine araştırmalar yapılmalı, önlemler alınmalıdır.

Çoğu kez kısa vadeli beklentilerle başvurulan yaratıcı muhasebe uygulamaları esasen uzun vadede hem işletmeler için hem de ilgili tüm taraflar için sorun yaratabilir. Bu nedenle Enron ile adını duyuran muhasebe skandallarının nedenleri arasında yaratıcı muhasebe uygulamaları gösterilebilir.

Bir dolandırıcılık eylemi olarak nitelendirilmese de farklı yöntem ve tekniklerle yapılan her bir yanıltıcı işlem bir kartopu gibi büyüyerek işletmelere ve ekonomilere büyük zararlar verebilir. Yaratıcı muhasebenin etik boyutu bu noktada ortaya çıkmaktadır.

Sonuç olarak; yaratıcı muhasebe uygulamalarının önlenmesi adına yalnızca yasal düzenlemelerin yeterli olmadığı aşikârdır. Bu konu üzerinde muhasebe alanındaki tüm kurumlarda etik eğitimi verilmelidir ve düzenleyici kurumlar, üniversiteler, yatırımcılar gibi tüm piyasa aktörlerinin birlikte çalışmaları sağlanmalıdır.

\section{KAYNAKÇA}

Akdoğan, H. ve Süklüm, N. (2019). Muhasebe Meslek Mensuplarının Yaratıcı Muhasebe Alg1 Düzeylerinin Tespiti: Çorum İli Uygulamasi/Determination Of Creative Accounting 
Perception Levels of Accounting Professionals: Çorum Province Application. Uluslararası Ekonomi İşletme ve Politika Dergisi, 3 (2), 219-238.

Akgün, İ. (2014). Yaratıcı Muhasebenin Ortaya Çıkış Nedenleri ve Finansal Raporlamaya Etkileri: Adana ve Kayseri Illerinde Bulunan Meslek Mensuplarma Yönelik Bir Araştırma. (Yayımlanmamış Yüksek Lisans Tezi), Niğde Üniversitesi/Sosyal Bilimler Enstitüsü, Niğde.

Aygün, D. (2013). Yaratıcı Muhasebe Stratejileri. Eskişehir Osmangazi Üniversitesi İktisadi ve İdari Bilimler Dergisi, 8 (2), 49-69.

Baralexis, S. (2004). Creative Accounting in Small Advancing Countries. Manageria Auditing Journal.

Çıtak, N. (2009). Yaratıcı Muhasebe Hileli Finansal Raporlama Mıdır? , Mali Çözüm Dergisi, (91), 81-112.

Demir V. ve O. Bahadır (2007). Muhasebe Manipülasyonu Yöntemler ve Teknikler. Mali Çözüm Dergisi, 84, 103-120.

Elitaş, L. B. (2013). Muhasebe Manipülasyonu ve Muhasebe Bilgi Kalitesine Etkisi. Muhasebe ve Finansman Dergisi, Nisan, 58, 41-53.

Genç, M. (2018). SPK'dan Bağımsız Denetim Yetkisi Almış Denetim Şirketlerindeki Denetçiler Açısından Yaratıcı Muhasebe Uygulamalarının Değerlendirilmesi. Uluslararası İktisadi ve İdari Incelemeler Dergisi, 17, 347-368.

Karahan, M., Çolak, M. (2019). Muhasebe Uygulamalarındaki Hata ve Hilelerin Tespiti: Üretim İşletmelerine Yönelik Araştırma, İşletme Araştırmaları Dergisi, 11 (3), 2290-2305.

Kırbaki, Y. ve M. Civriz. (2013). Yunanistan Krizi ve Yaratıcı Muhasebe Üzerine. Maliye Uzmanları Derneği Uzman Bakış Dergisi, 1 (1), 24-31.

Küçüksözen, C. ve Küçükkocaoğlu G. (2004). Finansal Bilgi Manipülasyonu: İMKB Şirketleri Üzerine Ampirik Bir Çalışma. MÖDAV Uluslararası Muhasebe Konferansında Sunulan Tebliğ, 03-05- Kasım: İstanbul.

Mert, İ. ve DeryaBaskan, T. (2020). Firma Bileşenlerinin Yaratıcı Muhasebeye Etkisi: BIST 50 Endeksindeki Firmalarda İnceleme, İşletme Akademisi Dergisi, 1 (1): 17-33.

Mulford, C. ve E. Comiskey (2002). The Financial Numbers Game. Detecting Creative Accounting Practices, New York: John Wiley \& Sons Inc.

Saltoğlu, M. (2003). Yaratıcı Muhasebede Özel Amaçlı Şirketlerin Rolü ve Enron Örneği. Muhasebe ve Denetime Bakış Dergisi, 10, 107-116.

Suzuki, Daisuke ve Yamada, Junpei. (2016). “Accounting Fraudand Accounting Standards: The Case of Toshiba's Fraudulent Accounting", 5th International Conference on Accounting, Auditing and Taxation (ICAAT 2016), 439- 449.

Türk, M. ve Arslan, C. A. (2017). Yöneticileri Yaratıcı Muhasebe Uygulamalarına İten Nedenler ve Bir Şirket Örneği. Gazi İktisat ve İşletme Dergisi, 3 (3), 91-108.

Varıcı, İ. ve Er, B. (2013). Muhasebe Manipülasyonu ve Firma Performansı İlişkisi: İMKB Uygulaması. Ege Akademik Bakış Dergisi, 1 (13), 43-52. 